

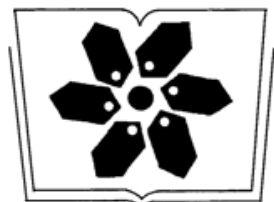

中国科学院科学出版基金资助出版
生 态 学 报

(SHENGTAI XUEBAO)

第 34 卷第 12 期 2014 年 6 月 (半月刊)

中国景观生态学发展历程与未来研究重点 陈利顶,李秀珍,傅伯杰,等 (3129) 城市景观格局演变的水环境效应研究综述 黄 硕, 郭青海 (3142) 多功能景观研究进展 汤 茜, 丁圣彦 (3151) 空间形态受限型城市紧凑发展研究——以厦门岛为例 黄 硕, 郭青海, 等 (3158) 紫金山森林公园降温效应影响因素 间伟姣, 孔繁花,尹海伟,等 (3169) 城市公园景观空间结构对其热环境效应的影响 冯悦怡, 胡潭高, 张力小 基于 OWA 的低丘缓坡建设开发适宜性评价——以云南大理白族自治州为例

刘炎序,彭 建, 韩忆楠,等 (3188) 生态安全条件下土地利用格局优化——以皇甫川流域为例 喻 锋, 李晓兵, 王 宏 (3198) 新疆玛纳斯河流域 2000-2010 年土地利用/覆盖变化及影响因素. 刘金巍, 靳甜甜,刘国华,等 (3211) 基于 GIS 和 RS 的赣江上游流域土地利用动态趋势分析 鲁燕飞,彭 芳,万 韵,等 (3224) 1954-2010 年三江平原土地利用景观格局动态变化及驱动力 刘吉平, 赵丹丹,田学智, 等 (3234) 基于斑块评价的三峡库区腹地坡耕地优化调控方法与案例研究 王永艳, 李阳兵, 郡景安,等 (3245) 贵州省山地-坝地系统土地利用与景观格局时空演变 李阳兵,姚原温,谢静,等 (3257) 中国西南地区土地覆盖情景的时空模拟 李 婧, 范泽孟, 岳天祥 (3266) 基于移动窗口法的峎江干旱河谷景观格局梯度分析. 张玲玲, 赵永华, 殷 莎, 等 (3276) 基于植被覆盖度的藏羚羊栖息地时空变化研究 赵海迪, 刘世梁, 董世魁, 等 (3285) 西南峡谷型喀斯特坡地土壤微生物量 $\mathrm{C} 、 \mathrm{~N} 、 P$ 空间变异特征 范夫静,黄国勤,宋同清,等 (3293) 峡谷型喀斯特不同生态系统的土壤微生物数量及生物量特征 谭秋锦, 宋同清, 彭晚霞, 等 (3302) 长三角地区土地利用时空变化对生态系统服务价值的影响 刘桂林, 张落成, 张 倩 (3311) 基于视觉廊道的青藏铁路沿线旅游动态景观评价 张瑞英,席建超,姚予龙,等 (3320) 基于 RS 与 GIS 的农村居民点空间变化特征与景观格局影响研究 任 平, 洪步庭, 刘寅,等 (3331) 生态系统保护现状及保护等级评估—以江西省为例 樊乃卿, 张育新, 吕一河,等 (3341) 崇明东滩盐沼植被变化对滩涂湿地促淤消浪功能的影响 任璘婧,李秀珍,杨世伦,等 (3350) 基于气候、地貌、生态系统的景观分类体系——新疆地区为例 .... 师庆东, 王 智, 贺龙梅, 等 (3359) 黄土丘陵沟壑区景观格局演变特征——陕西省延安市为例 钟莉娜, 赵文武, 吕一河, 等 (3368) 不同千扰背景下农业景观异质性——以巩义市为例 张晓阳,梁国付,丁圣彦 (3378) 山西高原草地景观的数量分类与排序 张先平, 李志琴, 王孟本, 等 (3386) 
山区夏季地表温度的影响因素 以泰山为例 孙常峰, 孔繁花, 尹海伟, 等(3396)

典型岩溶洼地土壤水分的空间分布及影响因素 张继光, 苏以荣, 陈洪松, 等 (3405)

基于移动窗口法的豫西山地丘陵地区景观异质性分析…… 李栋科, 丁圣彦, 梁国付, 等 (3414)

桂西北喀斯特区域植被变化趋势及其对气候和地形的响应 童晓伟, 王克林, 岳跃民, 等 (3425) 喀斯特与非喀斯特区域植被覆盖变化景观分析 以广西壮族自治区河池市为例

汪明冲, 王兮之, 梁钊雄, 等 (3435)

不同千扰背景下景观指数与物种多样性的多尺度效应 以巩义市为例

董翠芳, 梁国付, 丁圣彦, 等 (3444)

石栋-青冈常绿阔叶林土壤有机碳和全氮空间变异特征 杨 丹, 项文化, 方 晰, 等 (3452) 湘中丘陵区南酸柬阔叶林群落特征及群落更新 易 好, 邓湘雯, 项文化, 等 (3463) 基于 RBFN 的桂西北喀斯特区植被碳密度空间分布影响因素分析....... 张明阳, 王克林, 邓振华, 等 (3472)

期刊基本参数: CN 11-2031/Q * $1981 * \mathrm{~m} * 16 * 352 * \mathrm{zh} * \mathrm{P} * ¥ 90.00 * 1510 * 36 * 2014-06$

封面图说: 空间发展受限城市的厦门一一在我国城市化进程中, 中小城市在城镇体系建设中处于中间环节, 起到了联系大城市 和小城镇的作用。但是,每个城市由于发展历史、社会经济结构、自然地理形态等因素的不同,都有其发展的特性, 这些问题都必须要因地制宜地去把握。例如, 厦门岛相对隔离, 没有多余的发展空间, 该城市以居住功能为主, 城市 功能较为单一, 公共服务功能和商业服务功能比例较小。研究这样紧凑型的城市发展必须要考虑该城市结构转换 的承受力, 周边社会经济环境以及居民的生活习惯等。

彩图及图说提供: 陈建伟教授 北京林业大学 E-mail: cites.chenjw@163.com 


\title{
基于移动窗口法的豫西山地丘陵地区景观异质性分析
}

\author{
李栋科 ${ }^{1,2}$, 丁圣彦 ${ }^{1,2, *}$, 梁国付 ${ }^{1,2}$, 赵清贺 ${ }^{1,2}$, 汤 茜 $^{1,2}$, 孔令华 ${ }^{2}$ \\ (1. 教育部黄河中下游数字地理技术重点实验室, 开封 $475004 ; 2$. 河南大学环境与规划学院, 开封 475001)
}

\begin{abstract}
摘要: 研究典型区域景观异质性过程中, 对特征尺度的判断尤为重要。基于 $3 \mathrm{~S}$ 技术, 以豫西山地丘陵地区巩义市为研究区域, 在分析其景观组分与结构的基础上,采用半变异函数和移动窗口相结合的方法, 确定研究景观异质性的特征尺度,并在特征尺 度下选取西北一东南方向和东北一西南方向两条样线,分析研究区不同干扰背景下景观异质性的空间特征。结果表明:豫西巩 义地区总体上以旱地、建设用地、水浇地、草地和有林地景观类型为主, 其中旱地所占比例最大 ( $30.9 \%)$, 沟渠所占比例最小 (0.1\%) ; 根据特征尺度分析确定研究区巩义市景观异质性的合适尺度为 $1000 \mathrm{~m}$; 在特征尺度下,研究区景观破碎化以河谷平 原和丘陵为主的巩义东部偏南区域最高, 以人为干扰较少的南部低山有林地区最低, 景观多样性分布特征则呈现 4 个聚集中 心, 分别为北部河谷平原农业区、城市建成区、南部低山区和东南丘陵区; 不同干扰背景下,巩义地区景观异质性根据城市化程 度呈现以市区为中心向外辐射发展的特征, 同时受海拔高度因素影响较大, 即在海拔 $200 \mathrm{~m}$ 以下区域景观受人为干扰强烈, 海 拔 200- $500 \mathrm{~m}$ 丘陵区域受海拔因子和人为干扰因子共同作用,海拔 $500 \mathrm{~m}$ 以上区域海拔因子起主导作用。研究结果可为豫西 山地丘陵地区及同类地区景观异质性的研究尺度、景观格局优化和土地的有效管理提供依据。
\end{abstract}

关键词: 移动窗口法; 特征尺度;景观异质性;山地丘陵地区;河南西部

\section{Landscape heterogeneity of mountainous and hilly area in the western Henan Province based on moving window method}

\author{
LI Dongke ${ }^{1,2}$, DING Shengyan ${ }^{1,2, *}$, LIANG Guofu ${ }^{1,2}$,ZHAO Qinghe ${ }^{1,2}$, TANG Qian ${ }^{1,2}$, KONG Linghua ${ }^{2}$ \\ 1 Key Laboratory of Geospatial Technology For the Middle and Lower Yellow River Regions, Ministry of Education, Kaifeng 475004, China \\ 2 College of Environment \& Planning, Henan University, Kaifeng 475001, China
}

\begin{abstract}
In analyzing landscape heterogeneity in a typical area, appropriate selection of characteristic scale is very important. In this paper, Gongyi City, located in mountainous and hilly area of western Henan Province, has been chosen as our study area. Based on 3S technology, the landscape composition and structure of this area are analyzed. Meanwhile, the characteristic scale of landscape heterogeneity is determined by using the semi-variable function and moving window method. According to the characteristic scale, we selected two sample lines, which extend from the direction of NW to SE and the direction of $\mathrm{NE}$ to SW. These two sampled lines are set to analyze the spatial characteristics of landscape heterogeneity under different disturbances. Finally, the results show that landscape of the study area mainly consists of dry land, construction land, irrigated land, grassland and woodland. Among these landscape types, the dry lands have the largest proportion, accounting for $30.9 \%$ of the whole area, while the irrigation canals have the least area proportion, accounting for $0.1 \%$ of the whole area. Based on the semi-variable function and the moving window method, the characteristic scale for analyzing landscape heterogeneity of the study area is $1000 \mathrm{~m}$. Under this characteristic scale, the landscape fragmentation of the study area is mainly concentrated in the valley plain and hilly regions of the southeastern part
\end{abstract}

基金项目: 国家自然科学基金资助项目 $(41371195,41071118)$

收稿日期:2013-10-28; 修订日期:2014-04-01

*通讯作者 Corresponding author.E-mail: syding@ henu.edu.cn 
of the Gongyi City. The lowest fragmentation regions are in the forestland of southern hilly area of Gongyi City. Landscape diversity of the study area is characterized by four gathering centers, which are the northern valley plain agricultural area, constructed urban areas, the southeast hills and the low mountains in southern area. The first center exhibits the highest landscape diversity, while the landscape diversity of the other three is of the lowest. Under the influence of different disturbances, the landscape heterogeneity of the study area show features of radiating from the city center to surrounding rural area. In addition, landscape heterogeneity is also related to altitude in hilly regions. We find that the landscape heterogeneity has dramatic changes below $200 \mathrm{~m}$ because of strong human disturbance. However, at the altitude of 200-500 $\mathrm{m}$, human disturbance and altitude are combined to affect the landscape heterogeneity. In addition, at 500 meters above sea level, altitude is the dominant factor in influencing landscape heterogeneity. The results of this study can provide valuable guidance for further study on landscape pattern optimization and efficient management of land use in the mountainous and hilly area of western Henan Province.

Key Words : moving window method; characteristic scale; landscape heterogeneity; mountainous and hilly area; Western Henan Province

景观生态学注重异质性的研究 ${ }^{[1]}$, 其研究核心 是强调空间异质性与生态过程、尺度之间的相互作 用关系 ${ }^{[2-5]}$ 。景观异质性是空间斑块性和空间梯度 的综合反映 ${ }^{[6-7]}$, 是景观格局的重要特征。分析景观 异质性是研究景观功能和动态的基础, 对探索景观 结构与自然生态过程和社会经济活动的关系 ${ }^{[8-9] 、}$ 、研 究区土地资源合理利用和可持续发展均具有重要的 理论和现实意义 ${ }^{[10]}$ 。目前分析景观异质性多是在 深人理解各个景观指数对应公式及生态学意义基础 上 $^{[6,11-12]}$, 本着代表性、统一性和便于解释原则, 直 接用景观指数来表征景观异质性。但是, 景观指数 具有尺度效应、方向性及其他行为学特征 ${ }^{[2,13-15]}$, 目 前的研究较少综合以上特征对区域景观异质性进行 分析。

对于特定研究区域,选择合适的研究尺度对研 究结果尤为重要。有研究表明, 利用地统计学中的 半变异函数和移动窗口法都可以较好地分析景观指 数与空间变量的变异关系, 以及判定研究区域的特 征尺度。其中, 移动窗口法最早由 Whittaker 提出用 于分析植被沿水分梯度的变化 ${ }^{[16]}$, 随后被应用于城 乡交错带景观异质性等方面的研究 ${ }^{[17]}$, 其原理是在 研究区内选取一定大小的窗口进行移动, 形成新的 可在地理信息系统 (GIS) 中运算的数据图形 ${ }^{[18]}$, 实 现在区域或地区尺度上对景观指标的量化 ${ }^{[19-20]}$, 从 空间尺度上明确展示景观异质性特征; 半方差分析 是把统计相关系数的大小作为一个距离的函数来反 映一个采样点与其相邻采样点的空间关系的一种地
统计学方法,可用于分析特征尺度, 目前已被广泛应 用于多个领域。但是, 综合半变异函数和移动窗口 法来判定区域景观特征尺度的研究较少。

巩义市位于中岳嵩山北麓, 地貌类型多样, 地势 南高北低,山地、丘陵、平原类型齐全。近年来, 随着 区域社会经济发展,该地区的景观发生了巨大变化, 引起较多关注。但是, 大部分学者多从村域和农户 角度研究农田生态经济系统投人产出特征、农田系 统能量投人产出特征、农户迁居模式等 ${ }^{[21-23]}$, 以及从 恢复生态学角度研究森林景观恢复 ${ }^{[24]}$, 较少从景观 生态学角度研究不同干扰背景下景观异质性变异 特征。

因此,本研究基于地理信息系统,采用移动窗口 法和半变异函数相结合的方法, 以巩义市为研究区 域,探讨该区域景观异质性变化的特征尺度和景观 空间变异特征, 以期为研究区域土地的有效管理及 可持续利用提供依据。

\section{1 研究区概况}

作为豫西地区经济活力较高的三县之一的巩义 市 $^{[25]}$, 位于黄河中游地区, 处于国家第 2 台阶向第 3 台阶过渡边缘, 地理位置介于北纬 $34^{\circ} 31^{\prime}-34^{\circ} 52^{\prime}$, 东经 $112^{\circ} 49^{\prime}-113^{\circ} 17^{\prime}$, 在河南省省会郑州与古都洛 阳之间,南依嵩山, 北临黄河, 地势东南高西北低 (图 1)。巩义市土地总面积为 $1041 \mathrm{~km}^{2}$, 其中山地、丘陵 面积共 $919 \mathrm{~km}^{2}$, 河谷、平原面积 $117 \mathrm{~km}^{2}$, 属典型的 山地丘陵地区。山地分布着保护较完整的大面积林 
地, 植物资源丰富, 以温带落叶阔叶林为主; 低山丘 陵地区以荒山灌草丛、经济林和人工林为主; 河谷平 川地区以精耕细作的农业为主,或者是农林间作。 巩义地处暖温带半湿润偏干旱区, 属于温带季风气
候, 四季分明, 年平均气温 $14.4{ }^{\circ} \mathrm{C}, 7$ 月最热, 平均气 温 $27.3{ }^{\circ} \mathrm{C}, 1$ 月最冷, 平均气温 $0.2{ }^{\circ} \mathrm{C}$, 平均的降雨量 为 $640.9 \mathrm{~mm}$, 无霜期为 $220 \mathrm{~d}$ 。
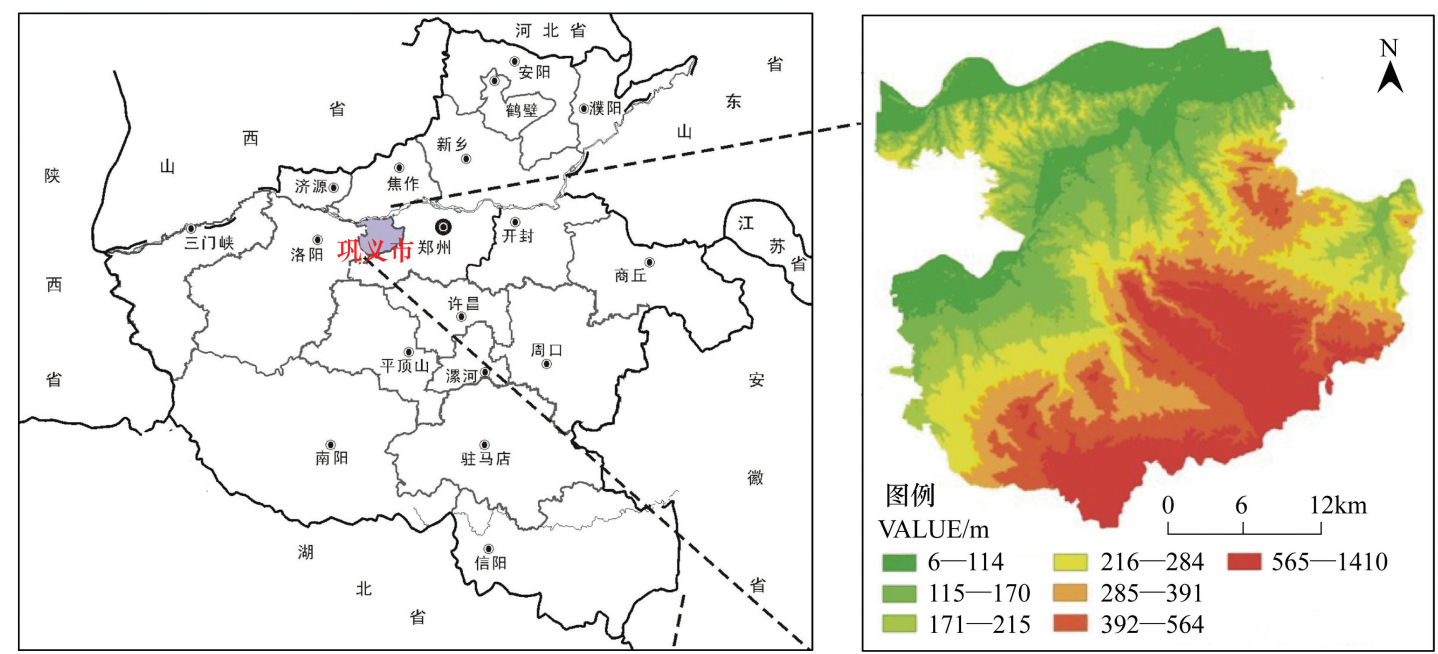

图 1 巩义市地理位置图及海拔梯度

Fig.1 Location and DEM of Gongyi City

\section{2 研究方法}

\section{1 数据处理}

\subsection{1 数据选择}

本研究选用的数据有: 2011 年巩义市土地利用 现状图 (当地政府部门提供, 比例尺较大, 数据涉 密), 比例尺为 $1: 1$ 万; 2012 年巩义实地调查得出的 景观类型组成、地貌特征和高程等相关数据。

\subsection{2 数据处理平台}

本研究所采用的数据处理软件主要为: Fragstats 3.3、ArcGIS 9.3 以及 SPSS 17.0、GS+ 7.0 数据分析等 软件。

\subsection{3 景观分类}

在对研究区景观功能认识的基础上, 根据土地 利用现状,将研究区景观类型划分为旱地、建设用 地、水浇地、草地、有林地、灌木林、河流、内陆滩涂、 道路、果园、水库坑塘、裸地、沟渠共 13 种景观类型, 并由矢量格式转换为栅格格式, 栅格大小为 $30 \mathrm{~m} \times$ $30 \mathrm{~m}$,进而进行格局指数的计算。

\section{2 景观指数的选取}

景观破碎化程度和多样性指数是衡量景观异质 性的重要指标。根据前人研究, 本文采用最大斑块 指数( LPI)、斑块密度 $(\mathrm{PD})$ 代表景观破碎化程度, 破
碎化程度越高, 空间异质性程度就越大, 反之破碎化 程度越低,空间异质性就越小; 采用香农多样性指数 (SHDI)、聚集度指数 (CONTAG)、景观均匀度指数 (SHEI) 代表研究区的景观多样性,其中,SHDI 代表 景观要素的多少和各景观要素面积占比的变化, CONTAG 描述景观中不同生态系统的团聚程度或延 展趋势, SHEI 则表示景观中不同生态系统的分配均 匀程度。

\subsection{1 最大斑块指数 (LPI)}

LPI 用于揭示最大斑块对整个景观 (或类型) 的 影响程度:

$$
\text { LPI }=\frac{\max _{j=1}^{a}\left(a_{i j}\right)}{A}
$$

式中, $a_{i j}$ 是景观中斑块的面积, $A$ 为景观总面积。

2.2.2 斑块密度指数(PD)

$\mathrm{PD}$ 反映斑块破碎化程度, 同时也反映景观空间 异质性程度。斑块密度越大, 破碎化程度就越高, 空 间异质性程度就越大, 反之, 破碎化程度越低, 空间 异质性就越小:

$$
\mathrm{PD}=\frac{1}{A} \sum_{j=1}^{m} N i
$$

式中, PD 整个景观的斑块密度, $N i$ 斑块数量, $A$ 景观 的总面积。 


\subsection{3 香农多样性指数 (SHDI)}

SHDI 值大小反映景观要素的多少和各景观要 素面积占比的变化:

$$
\text { SHDI }=-\sum_{i=1}^{m}\left(p_{i} \times \ln p_{i}\right)
$$

式中, $P_{i}$ 表示景观类型 $i$ 所占面积的比例, $m$ 表示景 观类型数。

\subsection{4 聚集度指数 (CONTAG)}

CONTAG 用于描述景观中不同生态系统的团聚 程度或延展趋势:

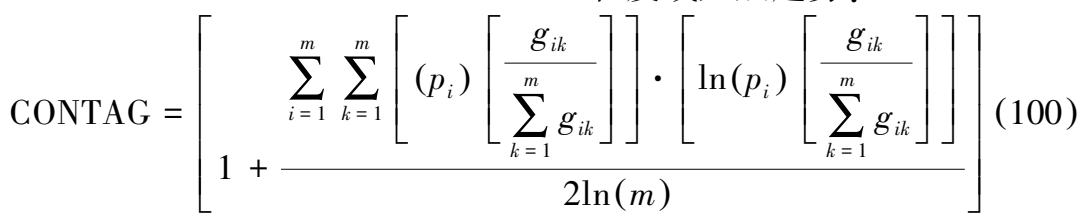

式中, $P_{i}$ 为第 $i$ 种景观类型所占景观总面积的比例, $m$ 为景观类型种类数。 $g_{i k}$ 为随机选择的两个相邻的 栅格属于类型 $i$ 和 $k$ 的概率。蔓延度指数通常是用 来度量景观斑块形状的复杂程度。取值范围: $0<$ CONTAG $\leqslant 100$ 。

\subsection{5 景观均匀度指数 (SHEI)}

SHEI 用于揭示景观中不同生态系统的分配均 匀程度。

$$
\text { SHEI }=\frac{-\sum_{i=1}^{m}\left(p_{i} \ln p_{i}\right)}{\ln m}
$$

式中, $P_{i}$ 为第 $i$ 种景观类型占景观总面积的比例, $m$ 为景观类型的种类数。

\section{3 移动窗口法}

首先, 将矢量格式的土地利用图转换为栅格格 式 $(30 \mathrm{~m} \times 30 \mathrm{~m})$; 其次, 将栅格数据导人 Fragstats 3.3 软件中,采用标准法计算研究区整体景观水平上最 大斑块指数 $(\mathrm{LPI})$ 、斑块密度 $(\mathrm{PD})$ 、香农多样性指数 (SHDI)、聚集度指数 ( CONTAG)、景观均匀度指数 (SHEI) 等景观指数; 利用移动窗口法, 移动窗口半 径分别设为 $500,750,1000,1250,1500,1750,2000$ $\mathrm{m}$, 从研究区左上角开始移动, 每次移动 1 个栅格, 计 算每个窗口内上述景观指数值 (根据 Fragstats3.3 使 用说明书, 对于窗口边界上不能被整分的栅格由 Fragstats3.3 软件自动判定取舍), 并赋予各个窗口的 中心栅格, 最终获得各个景观指数的空间分布栅 格图。

\section{4 半变异函数}

地统计学是一系列检测、估算变量在空间上的 相关关系和格局的统计方法 ${ }^{[26]}$,半方差分析 ( 又称 变异函数分析) 是地统计学中的一个重要组成部 分 ${ }^{[27-30]}$, 目前已在生态学、土壤学等领域应用。本研 究在移动窗口法的基础上, 采用地统计学中的半变
异函数方法判定景观特征尺度。半变异函数是把统 计相关系数的大小作为一个距离的函数。区域化变 量 $Z(x)$ 在点 $x$ 和 $x+h$ 处的值 $Z(x)$ 与 $Z(x+h)$ 差的 方差的一半称为区域化变量 $Z(x)$ 的半变异函 数 ${ }^{[31]}$, 记为 $r(h)$ 。定义为:

$$
r(x, h)=1 / 2 \operatorname{Var}[Z(x)-Z(x+h)]
$$

半变异函数曲线可以反映一个采样点与其相邻 采样点的空间关系。在半变异函数曲线上有两个非 常重要的点, 即间隔为 0 时的点和半变异函数趋势 平稳时的拐点, 由这两个点产生 4 个相应的参数: 块 金值(Nugget)、变程(Range)、基台值(Still)、偏基台 值 (Partial Still)。理论上, 空间变异是永恒存在的, 样点任意一方或两者共同作用产生了块金值 (Nugget), 记为 $C_{0}$, 当采样点间距增大时, $r(h)$ 从初 始的块金值达到一个相对稳定的常数, 该常数就为 基台值,记为 $C+C_{0}$ 。基台值与块金值间的差值为偏 基台值, 也就是结构方差 $C_{\text {。 }}$ 块金值与基台值比值 即为块基比, 记为 $C_{0} /\left(C+C_{0}\right)$, 其值可以估算随机因 素在空间总变量中重要性,进而反映变量在空间上 的变异程度。 $C_{0} /\left(C+C_{0}\right)$ 的比值大小代表空间变异 程度的高低, 其值越小, 说明空间自相关越明显, 也 就越稳定 ${ }^{[23,32-33]}$ 。本研究通过地统计软件 GS + 模 拟各个移动窗口下景观指数半变异函数模型, 根据 各个景观指数的 $C_{0} /\left(C+C_{0}\right)$ 值的变化规律, 分析不 同指数的空间变异特征对尺度变换的响应。结合前 人研究, 当比值达到稳定状态时, 即说明景观指数在 空间的变异趋于稳定, 可判定为研究区域景观的特 征尺度 ${ }^{[32-33]}$ 。

\section{5 样线设置}

巩义市地势是自东南向西北呈阶梯状急剧降 低, 分别为中山、低山、丘陵、河谷平川,样线选取尽 量覆盖所有景观类型。本文选取西北一东南方向样 线, 长为 $28.3 \mathrm{~km}$; 东北一西南方向样线, 长为 30.5 
$\mathrm{km}$; 然后基于特征尺度,利用 ArcGIS 软件中 3D Analyst 功能模块将两条样线上的信息提取并进行梯 度变化分析。

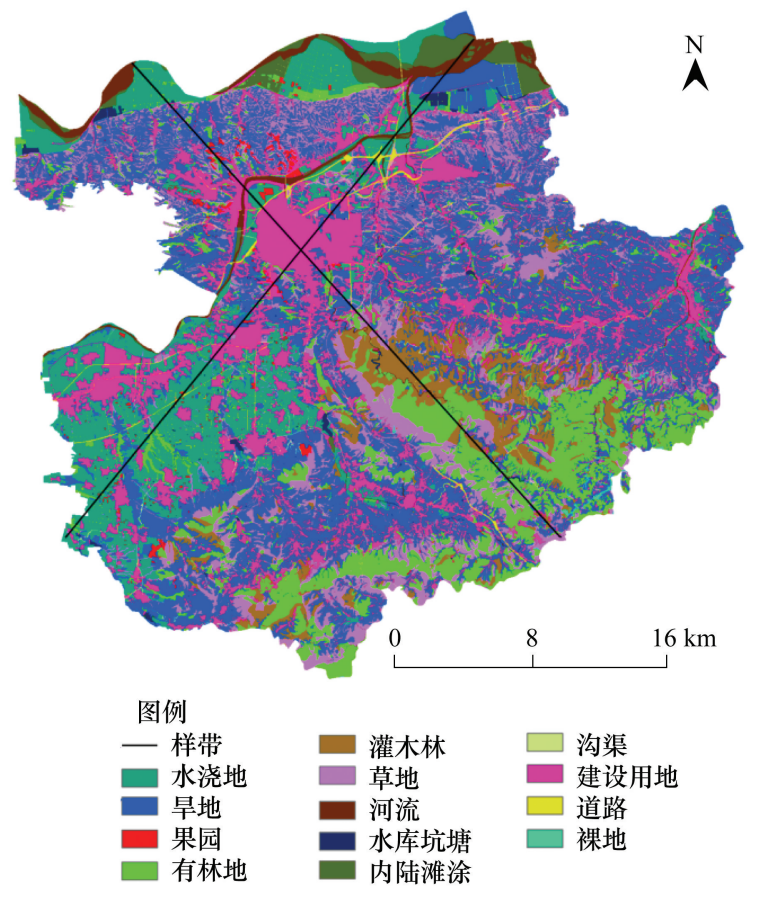

图 2 巩义市 2011 年景观分类图及样线设置

Fig.2 The classified map of Gongyi city and transects setting in 2011

\section{3 结果与分析}

\section{1 研究区景观的基本特征}

该地区占较大面积的景观类型是旱地, 面积为 $322.0 \mathrm{~km}^{2}$, 占总面积的 $30.9 \%$, 为该地区的基质; 其 次为建设用地, 水浇地, 草地和有林地的面积, 其面 积分别为 $190.0,142.4 、 135.2 \mathrm{~km}^{2}$ 和 $125.8 \mathrm{~km}^{2}$, 占总 面积的比例分别为 $18.2 \% 、 13.7 \% 、 13.0 \% 、 12.1 \%$; 其 他景观类型面积比较小,均未超过总面积的 $10.0 \%$ (表 1)。

\section{2 特征尺度}

根据景观格局指数空间变异特征值趋势图 (图 3 ), 在多个连续尺度上对区域景观斑块组成与构型 的空间变异特征进行探讨, 且在此基础上确定景观 斑块组成与构型的分析尺度 (特征尺度)。

图 3 中横坐标 ( $X$ 轴) 代表不同的窗口半径, 纵 坐标 ( $Y$ 轴) 代表的是块基比值 $\left(C_{0} /\left(C_{0}+C\right)\right)$ 。块 基比值越低,空间变异程度越低,空间自相关性越明 显, 也就越稳定; 越高, 空间变异程度越高, 越不稳
定。3 个景观格局指数的稳定性随着窗口半径的增 加呈现先增加后降低, 到一定数值后趋于稳定, 因此 可以进行特征尺度的判定。结果表明, 粒度 $750 \mathrm{~m}$ 和粒度为 $1000 \mathrm{~m}$ 时, 趋势图上出现明显的拐点。窗 口为 $500 \mathrm{~m}$ 和 $750 \mathrm{~m}$ 时呈现上升趋势, 变化不稳定, 因此 $750 \mathrm{~m}$ 并不能反映研究区域的特征尺度。3个 景观指数的空间变异特征值在 $1000 \mathrm{~m}$ 左右时开始 趋于稳定, 表明该尺度可以反映研究区景观格局变 化空间变异特征的内在尺度。另外, 尺度过大 （1250、1500、1750、2000 m) 会致使较多的空间信息 规律损失。因此,本研究选择 $1000 \mathrm{~m}$ 作为分析巩义 市景观格局的理想特征分析尺度。

表 1 各景观类型的面积及所占比例

Table 1 The area of the landscape types and their percentages

\begin{tabular}{lcc}
\hline $\begin{array}{l}\text { 景观斑块类型 } \\
\text { Landscape types }\end{array}$ & $\begin{array}{c}\text { 面积/ } \mathrm{km}^{2} \\
\text { Area }\end{array}$ & $\begin{array}{c}\text { 面积比例/\% } \\
\text { Area percentage }\end{array}$ \\
\hline 旱地 Dry land & 322.0 & 30.9 \\
建设用地 Construction land & 190.0 & 18.2 \\
水浇地 Rrrigated land & 142.4 & 13.7 \\
草地 Grassland & 135.2 & 13.0 \\
有林地 Woodland & 125.8 & 12.1 \\
灌木林 Shrub land & 53.6 & 5.1 \\
河流 River & 22.3 & 2.1 \\
内陆滩涂 Rnland tidal flat & 20.1 & 1.9 \\
道路 Road & 16.2 & 1.5 \\
果园 Orchard & 7.1 & 0.7 \\
水库坑塘 Pond and reservoir & 5.0 & 0.5 \\
裸地 Bare land & 1.9 & 0.2 \\
沟渠 Channel & 1.3 & 0.1 \\
\hline
\end{tabular}

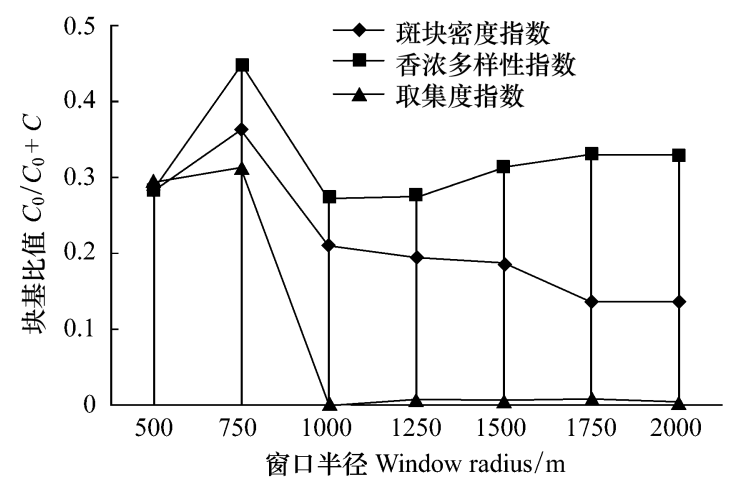

图 3 景观格局指数空间变异特征值趋势图

Fig.3 The trend of characteristic values of spatial heterogeneity within different extents

3.3 特征尺度下景观异质性特征

3.3.1 景观破碎化空间分析

2011 年研究区景观破碎化空间分布状况如图 4 
所示, 最大斑块指数有 3 个高值区, 分别为巩义市 区、西部河谷平原城镇建成地区和南部低山有林地 区,其中最大高值斑块为巩义市区。巩义市区和西 部河谷平原城镇建成区林地和绿地面积较少, 景观 类型以建设用地为主, 人为干扰剧烈; 而南部低山有 林地区, 由于封山育林, 人工油松林已初成规模, 林 地面积较大, 景观类型以有林地为主, 且海拔在 800 $\mathrm{m}$ 以上,地势较高, 人为干扰因素较弱。斑块密度在
以上 3 个地区较小, 是由于该地区优势类型斑块较 大且较完整,破碎化程度较低,空间异质性较小。斑 块密度较高地区位于巩义东部偏南区域, 大致由巩 义城区东南部近郊向巩义东部延展,地形以河谷平 原和丘陵为主, 地势较平坦, 景观类型多样, 受人类 活动影响较大, 所以该地区破碎化程度较高, 并且图 中显示两指数的相关性较高。
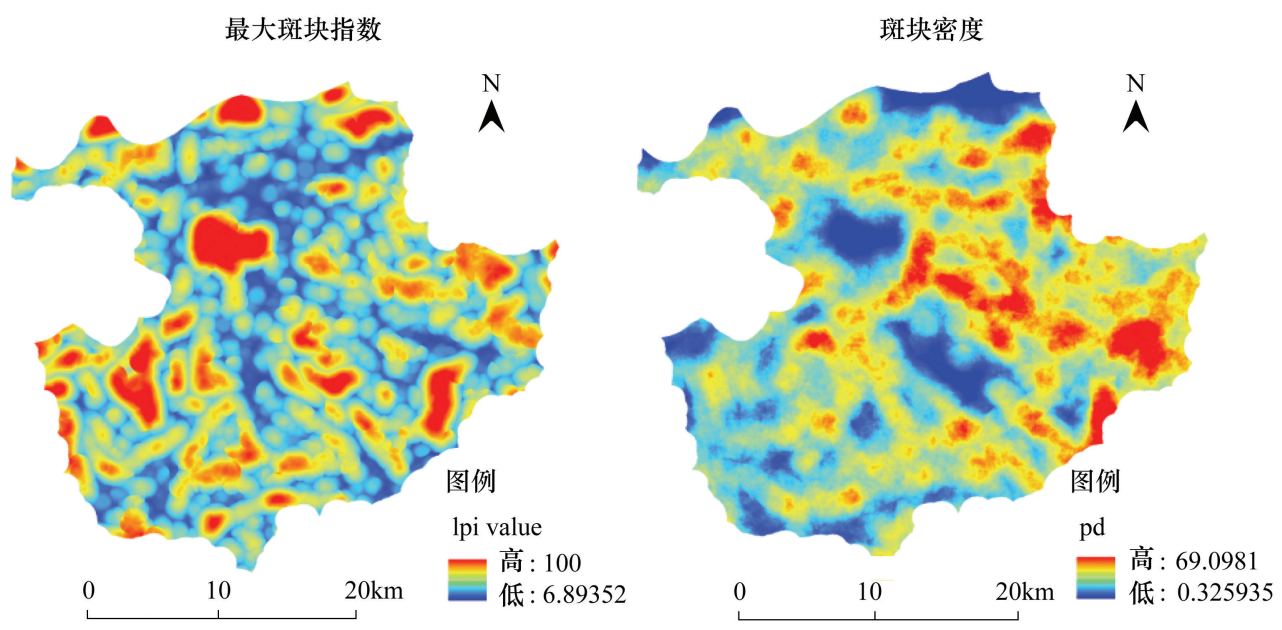

图 4 研究区景观破碎化空间分布

Fig.4 Spatial distribution of landscape fragmentation of the study area

\subsection{2 景观多样性空间分析}

景观多样性空间分布如图 5 所示,香农多样性 指数低值区出现在东南丘陵地区,南部低山地区和 中部建成区,尤其在有林地占绝对优势东南部地区， 景观类型较为单一,景观几乎是均质的,香农多样性 值较低;香农多样性指数高值出现在市区北部,该地 区为平原地区, 开发较早, 拥有水浇地、旱地、林地、
水域、建设用地等景观类型。景观均匀度指数表现 出与其相似分布状况。聚集度指数与景观多样性指 数有较高负相关性, 巩义市区和中部建成区, 以建设 用地、工矿用地为主, 受人类活动影响较大, 大斑块 团聚程度较高,呈规则形状分布; 东南丘陵地区和南 部低山丘陵地区以荒山灌丛、有林地为主, 不同生态 系统团聚程度低。
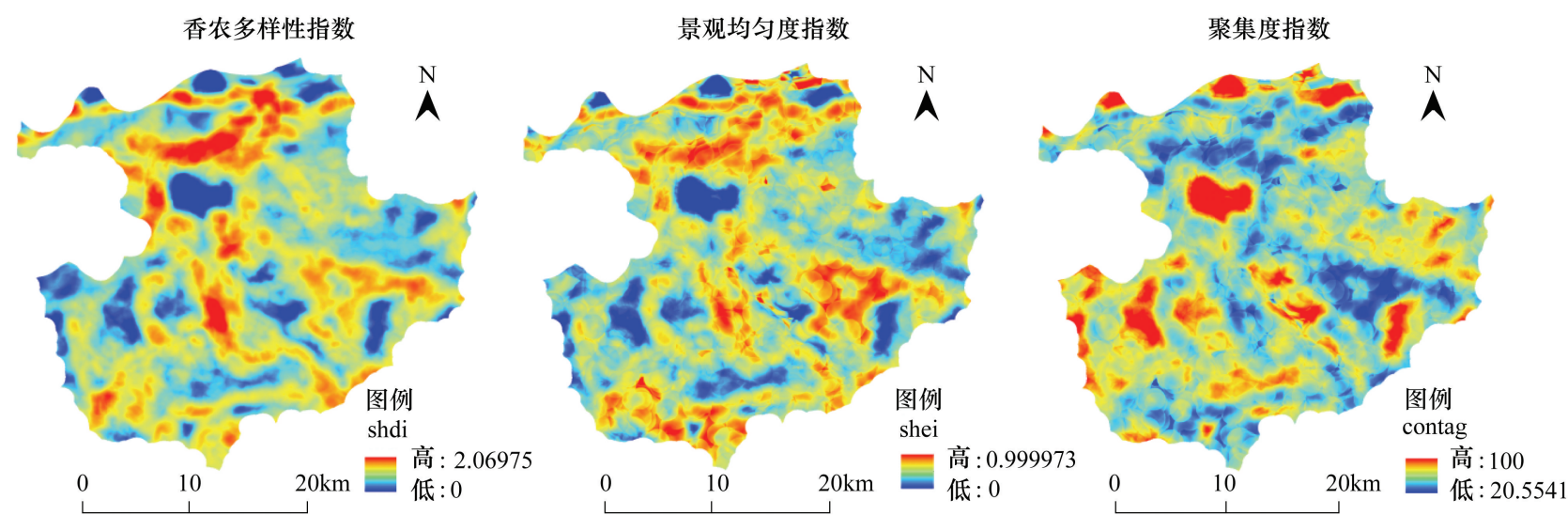

图 5 研究区景观多样性空间分布

Fig.5 Spatial distribution of landscape diversity of the study area 
3.4 不同干扰背景下景观异质性特征分析

\subsection{1 人为干扰背景下景观异质性分析}

在西北一东南方向上, 巩义市景观异质性特征 如图 6 所示。从远郊到近郊, 最大斑块指数总体呈 下降趋势, 在离中心城区约 $5 \mathrm{~km}$ 处达到拐点, 随后 急剧上升, 在市中心达到顶点, 随后在城市中心东南 近郊最大斑块指数迅速下降。这是由于城市建设用 地景观类型占绝对优势, 人为干扰剧烈所致。最大
斑块指数总体呈现 “ $\mathrm{W}$ ”形状; 聚集度指数呈现类似 结果。景观均匀度指数从远郊到近郊不断增加, 在 近郊离城市中心约 $5 \mathrm{~km}$ 处达到最大, 然后不断减 少, 在市中心达到最小值, 随着离城市中心越来越 远, 指数逐渐增加, 在远郊又呈下降趋势, 并向东南 方向不断延伸, 总体呈现“ $\mathrm{M}$ ”形状。香农多样性和 斑块密度也呈现类似结果。
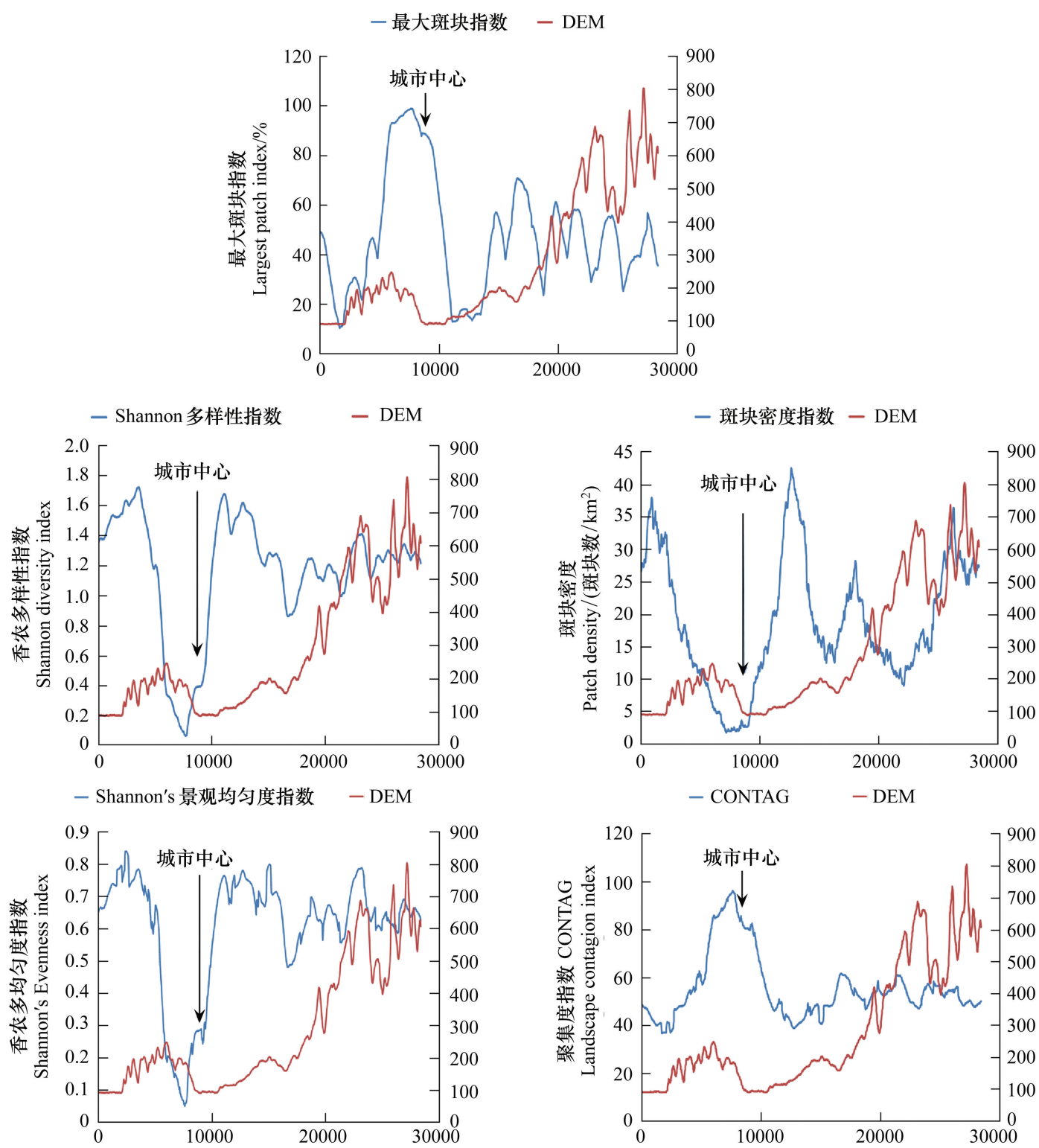

图 6 景观水平上的景观指数沿西北一东南方向样线变化

Fig.6 Change in landscape-level metrics along the NW-SE transect

在东北一西南方向上, 巩义市景观异质性特征 如图 7 所示。远郊到市中心距离约 $13 \mathrm{~km}$,最大斑块 指数和聚集度指数的峰值出现在市中心, 在近郊变
化较为剧烈, 出现多次的波动, 在市中心西南又有回 升趋势, 均匀度指数, 多样性指数和斑块密度出现类 似的特点, 在市中心出现谷值, 在近郊出现峰值, 在 
远郊指数相对较低。东北一西南方向的景观格局指 数在城市郊区波动具有相类似的特点, 变化明显的
地区出现在离市中心 $7 \mathrm{~km}$ 范围,有多次频繁的波 动, 景观类型复杂多样。
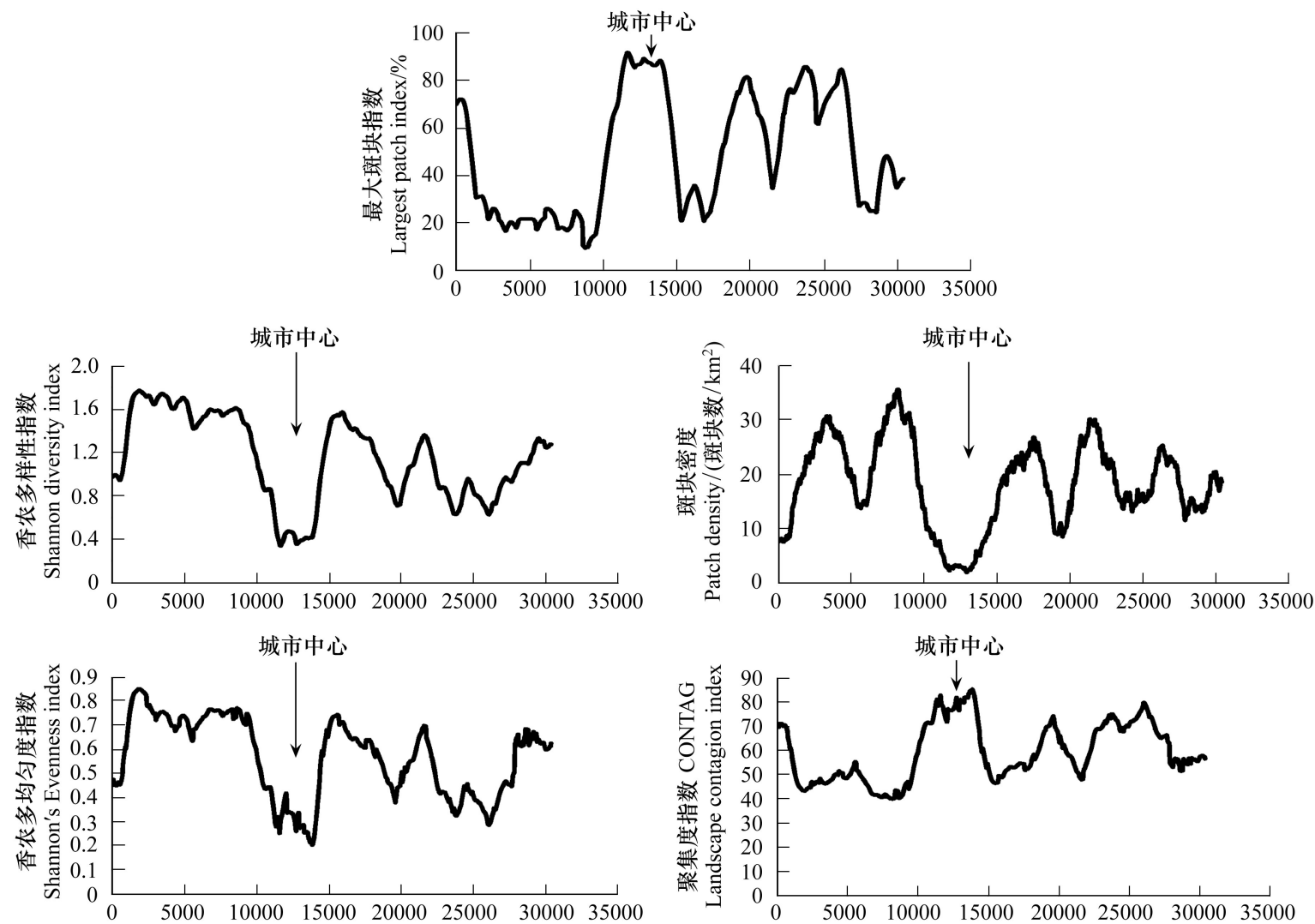

图 7 景观水平上的景观指数沿东北一西南方向样线变化

Fig.7 Change in landscape-level metrics along the NE-SW transect

通过对比两条样线可以发现,景观破碎化程度 以市区为中心向外辐射波动。在城市中心斑块密度 达到最低值, 是由于斑块类型较为单一, 主要以建设 用地为主,数量较少, 但每个斑块的面积较大, 从而 造成斑块密度较小。而在城市郊区, 斑块类型多样, 但每个斑块的面积较小, 从而造成斑块密度较大, 甚 至出现峰值。所以由城市中心到郊区景观由单一、 均质和连续的整体趋向于复杂、异质和不连续的斑 块镶嵌体。但是,由于选取的两条样线方向不同,景 观指数的变化趋势也有所不同。东北-西南方向景 观格局指数变化比较剧烈,这可能与研究区地势有 关,如巩义市中心向西南远郊方向地势较平坦,城市 建设用地和水浇地占较大优势, 受人为活动影响较 大, 而巩义市中心向东南远郊方向以低山为主, 有林 地斑块占较大优势, 建设用地和农业用地相对较少, 受人为活动影响较小。因此,推断巩义市景观异质 性变化受海拔因素影响较大。
3.4.2 景观异质性随海拔高度变化规律

豫西巩义市地处在嵩山北麓, 最高峰玉柱峰海 拔高度为 $1487 \mathrm{~m}$, 最低点巩义市沙鱼沟乡洛口滩, 海 拔为 $103.8 \mathrm{~m}$, 上下海拔落差为 $1383.2 \mathrm{~m}$, 其地势是 自南部向西北呈阶梯状急剧下降。南部和东南部分 地区海拔在 $1000 \mathrm{~m}$ 以上,属中山区域;由中山区域 向西北方向是一系列海拔在 500-1000 $\mathrm{m}$ 的低山, 构型成低山区; 由低山区域再向西北方向为广阔的 黄土丘陵区,其海拔为 200-500 m; 丘陵区西北向即 为其境内河谷平原区。

为了进一步分析景观异质性随海拔高度的变化 规律,结合图 2 , 图 6 和表 2 发现,在研究区西北-东 南方向上,各景观指数曲线图的极值均出现在低海 拔受人为干扰严重的城市建成区中心附近。对比最 大斑块指数 (LPI) 曲线、香农多样性指数 (SHDI) 曲 线和景观均匀度指数 (SHEI) 曲线发现, 自西北向东 南方向过城市中心后, 海拔高度升至 $200 \mathrm{~m}$ 出现了 
较为明显的较小波幅的连续波动, 说明随海拔高度 攀升, 自海拔 $200 \mathrm{~m}$ 后人为因素减少而海拔因子开 始显著作用于该研究区景观,同时也表明海拔 200$500 \mathrm{~m}$ 黄土丘陵区是海拔因子和人为干扰共同作用 的区域。当海拔进人 500-1000 m 低山区向高海拔 区延展的过程中, 景观异质性呈均衡平稳波动的态 势, 证明随着海拔梯度的快速跃升, 景观受海拔因子 的影响强烈, 人类干扰因素显著降低。以灌木林和 有林地为主的低山区景观由于海拔的变化被不同程 度的自然分割, 适度破碎化, 斑块数量略有增多, 进 而增加了生境类型, 更有利于生物多样性的保护。 另外最大斑块指数 (LPI) 曲线上峰弧度平滑, 略有跨 度,下峰急变斗转无弧度, 表明当地海拔落差变化较 快, 确实对景观产生了明显影响。对比斑块密度
(PD) 曲线和聚集度指数 (CONTAG) 曲线发现, 进一 步印证当海拔从 500-1000 m 低山区到高海拔区延 展的过程中出现较为明显的均衡平稳波动并维持在 一个适度水平上,表明随着海拔的攀升, 各类型斑块 面积占比趋于稳定,景观中不同生态系统的分配均 匀度适中, 人为干扰因素明显降低,海拔因子对 500 $\mathrm{m}$ 以上高海拔区域的景观变化起主导作用。

综上所述,豫西巩义地区海拔 $200 \mathrm{~m}$ 以下区域 景观受人为干扰强烈; 海拔 200-500 $\mathrm{m}$ 丘陵区域是 海拔因子和人为干扰因子共同作用的过度区域,且 随着海拔上升人为干扰因子对景观作用力逐步减 弱;海拔因子对 $500 \mathrm{~m}$ 以上高海拔区域的景观变化 起主导作用。

表 2 景观异质性与海拔的相关性

Table 2 Correlation between landscape heterogeneity and elevation

\begin{tabular}{lccccc}
\hline $\begin{array}{l}\text { 海拔 } / \mathrm{m} \\
\text { Elevation }\end{array}$ & $\begin{array}{c}\text { 最大斑块指数 } \\
\text { Largest Patch } \\
\text { index, LPI }\end{array}$ & $\begin{array}{c}\text { 聚集度指数 } \\
\text { Contagion Index } \\
\text { CONTAG }\end{array}$ & $\begin{array}{c}\text { 斑块密度指数 } \\
\text { Patch Density } \\
\text { PD }\end{array}$ & $\begin{array}{c}\text { Shannon 多样性指数 } \\
\text { Shannon's diversity } \\
\text { Index, SHDI }\end{array}$ & $\begin{array}{c}\text { 景观均匀度指数 } \\
\text { Shannon's Evenness } \\
\text { Index , SHEI }\end{array}$ \\
\hline$<200$ & $0.237^{* *}$ & $0.175^{* *}$ & $-0.292^{* *}$ & $-0.200^{* *}$ & $-0.142^{* *}$ \\
$200-500$ & $-0.376^{* *}$ & $-0.284^{* *}$ & 0.112 & $0.373^{* *}$ & $0.355^{* *}$ \\
$>500$ & $-0.330^{* *}$ & $-0.496^{* *}$ & $0.273^{* *}$ & $0.463^{* *}$ & $0.343^{* *}$ \\
\hline
\end{tabular}

\section{4 结论和讨论}

本文基于巩义市 2011 年 $30 \mathrm{~m} \times 30 \mathrm{~m}$ 栅格图像 数据,运用景观生态学、空间统计学的理论与方 法 $^{[34-35]}$,在地理信息系统技术支持下,对豫西山地丘 陵典型地区的巩义市的景观格局进行探讨。研究表 明,基于 GIS 的梯度和景观指数分析,利用移动窗口 的方法定量地测定景观空间格局及其变化规律是可 行的,且可实现景观指标的空间化与可视化,有利于 直观地了解区域景观格局和对干扰进行定量化 研究 ${ }^{[36-37]}$ 。

采用移动窗口计算景观格局指数时, 移动窗口 半径大小的选择对于分析景观格局的变化有重要影 响。在巩义市山地丘陵地区, 当移动窗口半径较小 时, 景观格局指数变化较大, 当移动窗口半径到 1000 $\mathrm{m}$ 或更大时, 景观格局指数变化相对比较平缓。本 研究结果表明,采用 $1000 \mathrm{~m}$ 移动窗口半径来分析研 究区景观格局时,既能保留梯度特征, 又能通过景观 指标的变化真实地反映空间格局的变化。在不同的
区域,随着景观组成和构型的变化, 景观异质性也在 不断变化, 分析景观格局时采用的移动窗口半径也 不一样, 但是本研究提出的方法, 可以为研究其它地 区时选择合适的研究尺度提供参考。

移动窗口形成的景观指数空间分布图,集中形 成了 4 个中心, 分别为巩义市区、东南丘陵地区、南 部低山地区和北部平原河川农业区, 这与巩义地区 空间格局的分布特点密切相关。中心地区周围约 5 $\mathrm{km}$ 处是景观格局指数变化最强烈的地区, 这 4 个中 心恰恰代表巩义 4 种不同程度的人为干扰区。市区 是人为干扰最大的区域,山地区人为干扰最小, 景观 表现为均质化的城市景观, 景观要素类型少, 最大斑 块指数大,多样性低; 河川平原和丘陵地区人为干扰 程度居中, 多样性高, 聚集度低。人类活动对巩义景 观的影响取决于离城市中心的距离, 沿两样线能清 楚识别出城市化中心, 巩义城市空间的扩展受其特 殊地形结构的影响, 主要从市区沿东部和北部进行 拓进和扩张。从另一个方面说明,所选用表示景观 组成和构型方面的指数, 如多样性指数、夢延度指数 
等可以很好地表征研究区景观格局特征,对于这些 指数深人地分析, 可以很好理解和区域景观异质性 特征。此外,除人为干扰外,海拔高度对研究区景观 异质性也起到相当重要的作用, 如在地势较为平坦 的低海拔地区 ( $200 \mathrm{~m}$ 以下) 受人为影响显著, 在中 海拔丘陵地区 $(200$ - $500 \mathrm{~m})$ 景观异质性受海拔高度 和人为干扰共同作用,而在 $500 \mathrm{~m}$ 以上的高海拔区 域,海拔因子对景观变化起主导作用。

景观格局指数是有尺度相关性的, 景观格局指 数本身的尺度相关性是怎样的? 在表征景观异质性 时,随尺度的变化又是怎样的? 这些问题在理解景 观异质性特征、特别是借用景观格局指数来分析时, 是急需要回答的问题,在下一步研究中还需要深人 考虑和分析。此外, 分析景观异质性要特别要从景 观不同的粒度和幅度来研究,研究中主要探讨了在 $30 \mathrm{~m}$ 粒度下,不同干扰程度地区的景观异质性的幅 度相关特征,而没有分析别的粒度, 以及不同粒度和 幅度组合下景观异质性的特征,这对全面理解景观 异质性特征有很重要意义,这也是在以后研究中需 要深人分析的地方。

\section{References :}

[ 1 ] Risser P G. Champaign: Illinois Natural History Survey // Landscape Ecology: Directions and Approaches, Special Publication Number 2. Champaign, IL: Illinois Natural History Survey, 1984

[ 2 ] Forman R T T, Godron M. Landscape Ecology. New York: John Wiley and Sons, 1986: 1-47.

[ 3 ] Naveh Z. Some remarks on recent developments in landscape ecology as a transdisciplinary ecological and geographical science. Landscape Ecology, 1991, 5(2): 65-73.

[ 4 ] Wu J G. Landscape Ecology, Cross-disciplinarity, and sustainability science. Landscape Ecology, 2006, 21(1) : 1-4.

[ 5 ] Turner M G. Landscape ecology: the effect of pattern on process. Annual Review of Ecology and Systematics, 1989, 20: 171-197.

[6] Wu J G. Landscape Ecology-Pattern, Process, Scale and Hierarchy. Beijing: Higher Education Press, 2007: 19-20.

[ 7 ] Pickett S T A, Cadenasso M L. Landscape ecology: spatial heterogeneity in ecological systems. Science, 1995, 269 (5222) : 331-334.

[ 8] Turner M G. Landscape ecology in North America: past, present, and future. Ecology, 2005, 86( 8) : 1967-1974.

[ 9 ] Forman R T T. Some general principles of landscape and regional ecology. Landscape Ecology, 1995, 10(3) : 133-142.

[10] Gao J B, Cai Y L. Spatial heterogeneity of landscape fragmentation at multi-scales. Scientia Geographica Sinica, $2010,30(5)$ : 742-748.

[11] Ye Y Q, Chen G J. An analysis on the landscape patterns based on the GIS technology in the upper Min River basin. Resources and Environment in the Yangtze Basin, 2006, 15(1) : 112-115.

[12] Sui X, Tong F, Yao C Q, Yang Z F. Landuses and landscape patterns of Qinghai Province in the Yellow River Basin. Bulletin of Soil and Water Conservation, 2007, 27(2) : 123-127.

[13] Wu J G. Landscape Ecology - Concepts and Theorieshinese. Journal of Ecology, 2000, 19(1) : 42-52.

[14] Bu R C, Hu M Y, Chang Y, Li X Z, He H S. A correlation analysis on landscape metrics. Acta Ecologica Sinica, 2005, 25 (10) : 2765-2775

[15] Shen W J, Wu J G, Lin Y B, Ren H, Li Q F. Effects of changing grain size on landscape pattern analysis. Acta Ecologica Sinica, 2003, 23(12) : 2506-2519.

[16] Whittaker R H. Vegetation of the Siskiyou Mountains, Oregon and California. New York : Ecological Society of America, 1960 : 30-49.

[17] McDonnell M J, Piekett S T A. Ecosystem structure and function along urban-rural gradients: An unexpected opportunity for ecology. Ecology, 1990, 71(4) : 1231-123.

[18] Baker W L, Cai Y M. The r.le programs for multiscale analysis of landscape structure using the GRASS geographical information system. Landscape Ecology, 1992, 7(4) : 291-302.

[19] Yin H W, Kong F H. Spatio-temporal gradient analysis is of urban green space in Ji'nan City. Acta Ecologica Sinica, 2005 , 25(11) : 3010-3018.

[20] Pickett S T A, Cadenasso M L, Grove J M, Nilon, C H, Pouyat R V, Zipperer W C, Costanza R. Urban ecological systems: Linking terrestrial ecological, physical, and socioeconomic components of metropolitan areas. Annual Review of Ecology and Systematics, 2001, 32 : 127-157.

[21] Li X J, Qiao J J. Impact of landform on input-output of man-land system in farmland of mountainous region: a micro-study of a small village in Wugou of Henan Province. Geographical Research, 2004, 23(6): 717-727.

[22] Qiao J J, Ding P F. Comparative study of energy input and output in villages farmland systems: the case of three types of villages in Gongyi county, Henan Province. Resources Science, 2004, 26(5) : 139-146.

[23] Qiao J J, Li X J. Impact of LULC on human-land systems: a micro-study of three villages in Gongyi City, Henan Province. Research of Soil and Water Conservation, 2006, 13(2) : 91-94.

[24] Chen J, Liang G F, Ding S Y. Landscape connectivity analysis for the forest landscape restoration: a case study of Gongyi City. Beijing: Acta Ecologica Sinica, 2012, 32(12) : 3773-3781.

[25] Qiao J J. Rural Territorial Economy of China. Beijing: Science Press, 2008: 128-129. 
[26] Journal A, Huijbregis C. Mining Geostatistics. New York: Academic Press, 1978.

[27] Matheron G. Principles of geostatistics. Economic Geology, $1963,58(8)$ : 1246- 1266.

[28] Griffith J A, Martinko E A, Price K P. Landscape structure analysis of Kansas at three scales. Landscape Urban Plan, 2000 , $52(1): 45-61$.

[29] Fortin M J, Boots B, Csillag F, Remmel T K. On the role of spatial stochastic models in understanding landscape indices in ecology. Oikos, 2003, 102(1): 203-212.

[30] Smith A C, Koper N, Francis C M, Fahrig L. Confronting collinearity: comparing methods for disentangling the effects of habitat loss and fragmentation. Landscape Ecology, 2009, 24 (10) : 1271-1285.

[31] Cai B F, Yu R. Comparison on spatial scale analysis methods in landscape ecology. Acta Ecologica Sinica, 2008, 28 ( 5 ): 2280-2282.

[32] Xue D D, She G H, Wen X R, Sun H H, Li Q W, Zhou Y C. Scale effect of landscape pattern of Nanjing Zhongshan Scenic Spot based on statistic analysis. Journal of Southwest Forestry University, 2012, 32(1) : 30-35.

[33] Yue W Z, Xu J H, Xu L H, Tan W Q, Mei A X. Spatia variance characters of urban synthesis pattern indices at different scales. Chinese Journal of Applied Ecology, 2005, 16 (11): 2053-2059.

[34] Xiao D N. Landscape Ecology. Beijing: Science Press, 2003: 89- 124.

[35] Yu Z R. Landscape Ecology. Beijing: Chemical Industry Press, 2008: 44-78.

[36] Liu X, Guo Q X. Landscape pattern in Northeast China based on moving window method. Chinese Journal of Applied Ecology, 2009, 20(6) : 1415-1422.

[37] Wang J, Sun J, Yang X J, Liu W Z, Zaccarelli N, Zhang X L, Wang X Y. An analysis of disturbance on social-ecological system a tmultiple scales based on NDVI, case study in Yuzhong county of Gansu Province. Acta Ecologica Sinica, 2009, 29 (3) : 1622-1628.

\section{参考文献:}

[6] 邬建国. 景观生态学一一格局、过程、尺度与等级. 北京: 高等 教育出版社, 2007: 19-20

[10］高江波，蔡运龙. 区域景观破碎化的多尺度空间变异研究. 地
理学报, 2010, 30(5): 742-748.

[11] 叶延琼, 陈国阶. GIS 支持下的岷江上游流域景观格局分析. 长江流域资源与环境, 2006, 15(1)：112-115

[12] 隋欣, 童飞, 姚长青, 杨志峰. 黄河流域青海片土地利用景观 空间格局分析. 水土保持通报, 2007, 27(2): 123-127.

[13] 邬建国. 景观生态学一概念与理论. 生态学杂志, 2000, 19 (1) : 42-52.

[14] 布仁仓, 胡远满, 常禹, 李秀珍, 贺红士. 景观指数之间的相 关分析. 生态学报, 2005, 25(10) : 2765-2775.

[15］申卫军, 邬建国, 林永标, 任海, 李勤奋. 空间粒度变化对景 观格局分析的影响. 生态学报, 2003, 23(12) : 2506-2519.

[19］尹海伟，孔繁花. 济南市城市绿地时空梯度分析. 生态学报, 2005, 25(11) : 3010-3018.

[21］李小建, 乔家君. 地形对山区农田人地系统投人产出影响的 微观分析一一河南省巩义市吴沟村的实证研究. 地理研究, 2004, 23(6) : 717-727.

[22] 乔家君，丁鹏飞. 村域农田系统能量投人产出特征比较研 究——以河南省巩义市 3 个不同类型村为例. 资源科学, 2004, 26( 5) : 139-146.

[23] 乔家君, 李小建. 土地利用/土地覆被对人地系统的影响分 析一以河南省巩义市 3 个不同类型村为例. 水土保持研究, 2006, 13(2) : 91-94.

[24] 陈杰, 梁国付, 丁圣彦. 基于景观连接度的森林景观恢复研 究——以巩义市为例. 生态学报, 2012, 32(12) : 3773-3781.

[25] 乔家君. 中国乡村地域经济论. 北京: 科学出版社, 2008: 128-129.

[31] 蔡博峰, 于嵘. 景观生态学中的尺度分析方法. 生态学报, 2008, 28(5) : 2280-2282.

[32］薛冬冬, 余光辉, 温小荣, 孙浩晗, 李勤文, 周易春. 基于地 统计分析的南京钟山风景区景观格局尺度效应分析. 西南林 业大学学报, 2012, 32(1) : 30-35.

[33] 岳文泽, 徐建华, 徐丽华, 谈文琦, 梅安新. 不同尺度下城市 景观综合指数的空间变异特征研究. 应用生态学报, 2005,16 (11) : 2053-2059.

[34] 肖笃宁. 景观生态学. 北京: 科学出版社, 2003: 89-124.

[35] 宇振荣. 景观生态学. 北京: 化学工业出版社, 2008: 44-78.

[36] 刘昕, 国庆喜. 基于移动窗口法的中国东北地区景观格局. 应 用生态学报, 2009, 20(6) : 1415-1422.

[37] 王俊, 孙晶, 杨新军, 刘文兆, Zaccarelli $\mathrm{N}$, 张向龙, 汪兴玉. 基于 NDVI 的社会-生态系统多尺度干扰分析一一甘肃省榆 中县为例. 生态学报, 2009, 29(3): 1622-1628. 


\section{ACTA ECOLOGICA SINICA Vol.34,No.12 June,2014(Semimonthly) CONTENTS}

Development history and future research priorities of landscape ecology in China

CHEN Liding, LI Xiuzhen, FU Bojie, et al (3129)

Research review on effects of urban landscape pattern changes on water environment

HUANG Shuo, GUO Qinghai (3142)

A review of multifunctional landscape

TANG Qian, DING Shengyan (3151)

Compact development of space-limited city : a case study of Xiamen Island

HUANG Shuo, GUO Qinghai, TANG Lina (3158)

Analysis of factors contributing to the cooling effects of Purple Mountain Forest Park

YAN Weijiao, KONG Fanhua, YIN Haiwei, et al (3169)

Impacts of structure characteristics on the thermal environment effect of city parks

FENG Yueyi, HU Tangao, ZHANG Lixiao (3179)

Suitability assessment for building land consolidation on gentle hillside based on OWA operator: a case in Dali Bai Nationality

Borough in Yunnan, China

LIU Yanxu, PENG Jian, HAN Yinan, et al (3188)

Optimization of land use pattern based on eco-security : a case study in the huangfuchuan watershed

YU Feng, LI Xiaobing, WANG Hong (3198)

Analysis of land use/cover change from 2000 to 2010 and its driving forces in Manas River Basin, Xinjiang

LIU Jinwei, JIN Tiantian, LIU Guohua, et al (3211)

Dynamic trend analysis of land use change in the ganjiang upstream watershed by using RS and GIS techniques

LU Yanfei, PENG Fang, WAN Yun, et al (3224)

Landscape pattern dynamics and driving forces analysis in the Sanjiang Plain from 1954 to 2010

LIU Jiping, ZHAO Dandan, TIAN Xuezhi, et al (3234)

Optimizing theory and case studies of cultivated slope land in the center of three gorges reservoir area based on patch-scale land

evaluation

WANG Yongyan, LI Yangbing, SHAO Jingan, et al (3245)

Spatial-temporal evolution of land use and landscape pattern of the mountain-basin system in Guizhou Province

LI Yangbing, YAO Yuanwen, XIE Jing, et al (3257)

Spatio-temporal simulation of land cover scenarios in southwestern of China

LI Jing, FAN Zemeng, YUE Tianxiang (3266)

Gradient analysis of dry valley of Minjiang River landscape pattern, based on moving window method

ZHANG Lingling, ZHAO Yonghua, YIN Sha, et al (3276)

Study on spatio-temperal change of Tibetan Antelope's habitat based on vegetation coverage

ZHAO Haidi, LIU Shiliang, DONG Shikui, et al (3285)

Spatial heterogeneity of soil microbial biomass carbon, nitrogen, and phosphorus in sloping field in a groge Karst region,

Southwest China

FAN Fujing, HUANG Guoqin, SONG Tongqing, et al (3293)

Characteristics of soil microbial populations and biomass under different ecosystems in a canyon karst region

TAN Qiujin, SONG Tongqing, PENG Wanxia, et al (3302)

Spatial and temporal dynamics of land use and its influence on ecosystem service value in Yangtze River Delta

LIU Guilin, ZHANG Luocheng, ZHANG Qian (3311)

Evaluation of tourism dynamic landscape along Qinghai-Tibet railway based on the visual corridor

ZHANG Ruiying, XI Jianchao, YAO Yulong, et al (3320)

A study of spatial evolution characteristics of rural settlements and influences of landscape patterns on their distribution using GIS and RS REN Ping, HONG Buting, LIU Yin, et al (3331) 
Assessing the ecosystem conservation status and priority: a case study from Jiangxi Province, China

FAN Naiqing, ZHANG Yuxin, LÜ Yihe, et al (3341)

The impact of salt marsh change on sediment accumulation and wave attenuation at the East Chongming Island

REN Linjing, LI Xiuzhen, YANG Shilun, et al (3350)

Landscape classification system based on climate, landform, ecosystem : a case study of Xinjiang area

SHI Qingdong, WANG Zhi, HE Longmei, et al (3359)

Analysis of landscape pattern evolution characteristic in the hilly and gully area of loess plateau: a case study in Yan'an City,

Shaanxi Province

ZHONG Lina, ZHAO Wenwu, LV Yihe, et al (3368)

Analysis of the characteristics of agro-landscape heterogeneity under the different disturbances:a case study of Gongyi City

ZHANG Xiaoyang, LIANG Guofu, DING Shengyan (3378)

Classification and ordination of grassland landscape in the Shanxi Plateau

ZHANG Xianping, LI Zhiqin, WANG Mengben, et al (3386)

Analysis of factors affecting mountainous land surface temperature in the summer: a case study over Mount Tai

SUN Changfeng, KONG Fanhua, YIN Haiwei, et al (3396)

Research on spatial distribution and influencing factor of soil moisture in typical depression area of karst region

ZHANG Jiguang, SU Yirong, CHEN Hongsong, et al (3405)

Landscape heterogeneity of mountainous and hilly area in the western Henan Province based on moving window method

LI Dongke, DING Shengyan, LIANG Guofu, et al (3414)

Trends in vegetation and their responses to climate and topography in northwest Guangxi

TONG Xiaowei, WANG Kelin, YUE Yuemin, et al (3425)

Landscape pattern analysis on change of fractional vegetation cover between karst and no-karst areas: a case study in Hechi

District, Guangxi Zhuang Autonomous Region

WANG Mingchong, WANG Xizhi, LIANG Zhaoxiong, et al (3435)

Multi-scale effects for landscape metrics and species diversity under the different disturbance: a case study of Gongyi City

DONG Cuifang, LIANG Guofu, DING Shengyan, et al (3444)

Spatial heterogeneity of soil organic carbon and total nitrogen concentrations in a Lithocarpus glaber-Cyclobalanopsis glauca evergreen broadleaved forest

YANG Dan, XIANG Wenhua, FANG Xi, et al (3452)

The characteristics and regeneration of the Choerospondias axillaries broad-leaved community in the hilly region of central Hunan

Province, China

YI Hao, DENG Xiangwen, XIANG Wenhua, et al (3463)

Factors influencing the spatial distribution of vegetation carbon density in karst landscapes of Northwest Guangxi: a case study

based on radial basis function network model

ZHANG Mingyang, WANG Kelin, DENG Zhenhua, et al (3472) 


\section{《生态学报》2014 年征订启事}

《生态学报》是由中国科学技术协会主管, 中国生态学学会、中国科学院生态环境研究中心主办的生态学 高级专业学术期刊,创刊于 1981 年,报道生态学领域前沿理论和原始创新性研究成果。坚持“百花齐放,百家 争鸣” 的方针, 依靠和团结广大生态学科研工作者, 探索生态学奥秘, 为生态学基础理论研究搭建交流平台, 促进生态学研究深人发展, 为我国培养和造就生态学科研人才和知识创新服务、为国民经济建设和发展服务。

《生态学报》主要报道生态学及各分支学科的重要基础理论和应用研究的原始创新性科研成果。特别欢 迎能反映现代生态学发展方向的优秀综述性文章; 研究简报; 生态学新理论、新方法、新技术介绍; 新书评价和 学术、科研动态及开放实验室介绍等。

《生态学报》为半月刊,大 16 开本, 280 页, 国内定价 90 元/册, 全年定价 2160 元。

国内邮发代号: 82-7,国外邮发代号: M670

标准刊号:ISSN 1000-0933 CN 11-2031/Q

全国各地邮局均可订阅，也可直接与编辑部联系购买。欢迎广大科技工作者、科研单位、高等院校、图书 馆等订阅。

通讯地址: 100085 北京海淀区双清路 18 号 电

E-mail: shengtaixuebao@ rcees.ac.cn
网

话: (010)62941099; 62843362

址: www.ecologica.cn

编辑部主任 孔红梅 执行编辑 刘天星 段 靖

\author{
生 态 学 报 \\ (SHENGTAI XUEBAO) \\ (半月刊 1981 年 3 月创刊)
}

第 34 卷 第 12 期 (2014 年 6 月)

\section{ACTA ECOLOGICA SINICA}

( Semimonthly, Started in 1981)

Vol. 34 No. 12 (June, 2014)

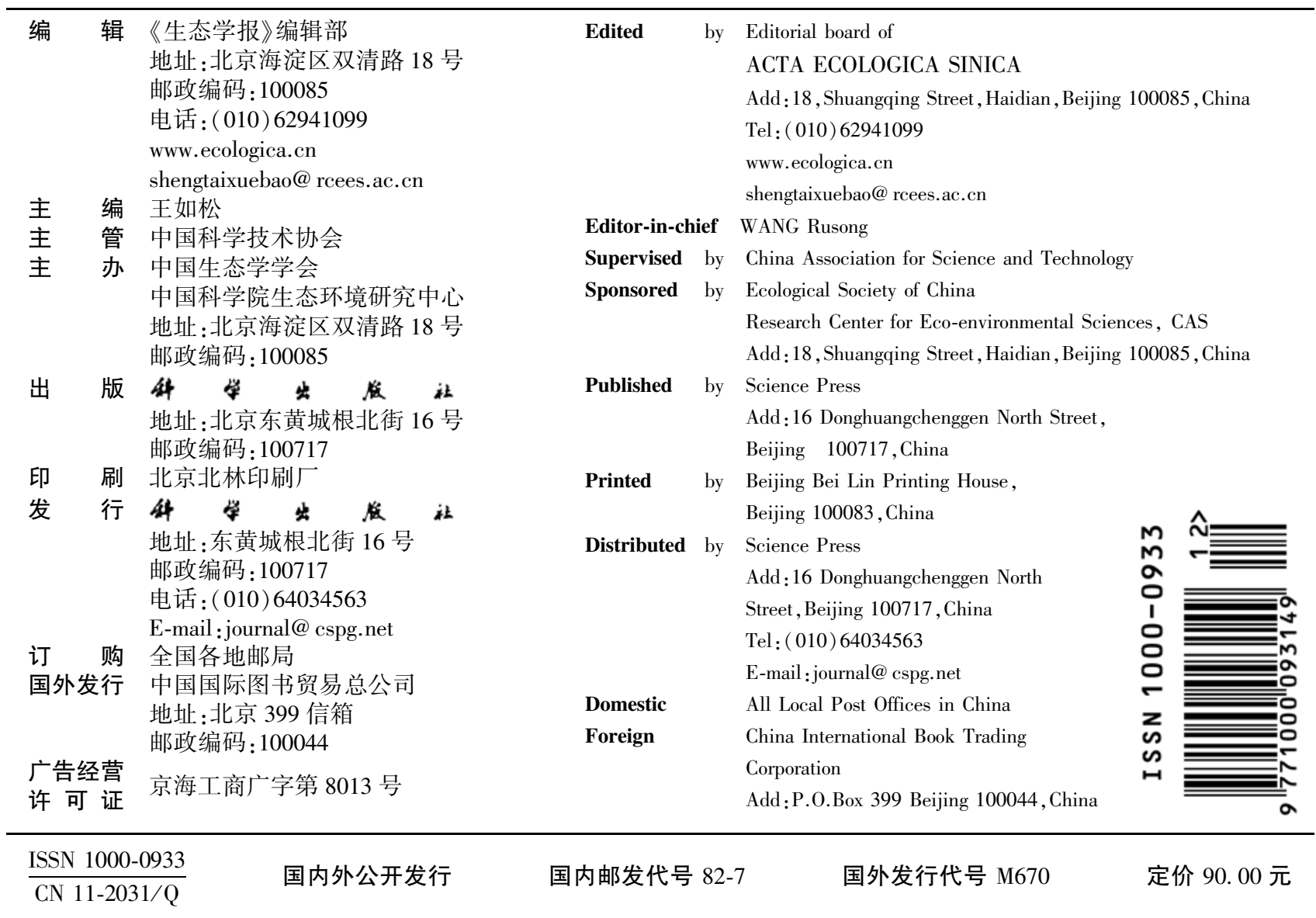

